\title{
Genetic Transformation in Proteus mirabilis
}

\author{
By A. J. VAN RENSBURG \\ Institute for Pathology, P.O. Box 2034, Pretoria, South Africa \\ (Accepted for publication 29 March 1971 )
}

\begin{abstract}
SUMMAR Y
A method is described for the isolation of biologically active DNA from Proteus mirabilis strain I 3 which could transform auxotrophic mutants of $P$. mirabilis to prototrophy. This DNA preparation did not transform similar mutants of $P$. vulgaris. Optimal conditions for transformation were $\mathrm{pH} 8.5$ to 9.5 for the lysate during DNA extraction, DNA concentration of $16 \mu \mathrm{g} . / \mathrm{ml}$. and growth of recipient cells for $5 \mathrm{~h}$. before exposure to DNA.
\end{abstract}

\section{INTRODUCTION}

Attempts to transform Enterobacteriaceae have met with mixed success. Restoration of prototrophy in spheroplasts obtained from auxotrophic Escherichia coli strains has been reported by Chargaff, Schulman \& Shapiro (1957) and Rudchenko (1968). Transformation of $\mathrm{gal}^{-}$strains of $E$. coli by $\lambda d g$ was obtained in the presence of helper phage (Kaiser \& Hogness, I960). Mehta, Rege \& Sreenivasan (1962) and Avadhani, Mehta \& Rege (I969) used wild-type DNA to transform an auxotrophic mutant of $E$. coli strain I I3-3 to nutritional independence.

Transformation of organisms belonging to the Proteus-Providence group has not been reported. Van Rensburg (1969) demonstrated that spheroplasts prepared from Proteus mirabilis in the early (but not late) growth phase could be transfected. In the light of this knowledge it was decided to re-investigate previous transformation attempts. For this purpose, strains from $\boldsymbol{P}$. hauseri were used. This group of serologically related Gramnegative bacteria is subdivided into two biochemically distinct subgenera, $P$. mirabilis and P. vulgaris (Kauffmann, I966).

\section{METHODS}

Bacteria. Proteus mirabilis strain 13 (Coetzee \& Sacks, I960) and triple mutants tyr-I leu-I met-I, tyr-I ade-I his-I and leu-I met-I his-I derived from it by multiple-step $N$ methyl- $N$ '-nitro- $N$-nitrosoguanidine treatment (Adelberg, Mandel \& Chen, 1965). Mutants ade-I and arg-I of $P$. mirabilis strain 5006 (Coetzee \& Smit, I970) and a ura-I mutant of $P$. vulgaris strain 69 (Coetzee, 1963). The incubation temperature was $30^{\circ}$.

Media. The minimal medium (Prozesky, 1967) was supplemented with amino acids (50 $\mu \mathrm{g} . / \mathrm{ml}$.) or uracil $(2.5 \mu \mathrm{g} . / \mathrm{ml}$.) when necessary.

Isolation and purification of transforming DNA. DNA extraction was performed at $\circ$ to $4^{\circ}$ except where stated otherwise. A modification of the method of Avadhani et al. (I969) was used. Packed cells (4 g. dry wt) were washed twice with citrate + saline (SSC) $(0.15 \mathrm{M}-\mathrm{NaCl}+0.015 \mathrm{M}$ sodium citrate, $\mathrm{pH} 7.0$ ) and resuspended in $100 \mathrm{ml}$. of this buffer. The $\mathrm{pH}$ of the suspension was adjusted to $9 \cdot 0$. Five $\mathrm{ml}$. I0\% sodium dodecyl sulphate solution were added to the suspension, which was kept at room temperature for $15 \mathrm{~min}$. to facilitate lysis. To the lysate $33 \mathrm{ml}$. chloroform $+10 \mathrm{ml}$. isoamyl alcohol, chilled to $-20^{\circ}$, were 
added and the mixture then shaken at $60 \mathrm{cyc} / \mathrm{min}$. on a reciprocal shaker. After $30 \mathrm{~min}$. the milky solution was centrifuged at $5000 \mathrm{~g}$ for $15 \mathrm{~min}$. The supernatant was removed and the chloroform + amyl alcohol treatment repeated until it was clear. A double volume of chilled $95 \%$ ethanol was added to the solution to precipitate DNA. The precipitate was collected with a glass rod and redissolved in O.I M-SSC. Lipids were removed by shaking $10 \mathrm{ml}$. DNA solution with $0.2 \mathrm{ml}$. $10 \%$ sodium deoxycholate. After precipitation with ethanol the precipitate was again dissolved in $0 . \mathrm{I} \mathrm{M}-\mathrm{SSC}$ and the detergent treatment repeated to remove all lipids in the solution. RNA was removed by incubation with $0.2 \%$ RNase at $15^{\circ}$ for $20 \mathrm{~min}$. The RNase was first incubated at $80^{\circ}$ and a pH of 5.0 for $10 \mathrm{~min}$. to destroy DNase activity which may be present in the enzyme preparations. DNA was precipitated by addition of a double volume of chilled isopropanol to the solution. The fibrous DNA precipitate was stored under $95 \%$ ethanol in the cold. When required for use the DNA precipitate was dissolved in sterile isotonic saline to a concentration of about $300 \mu \mathrm{g}$. $/ \mathrm{ml}$. Protein was determined by the method of Lowry, Rosebrough, Farr \& Randall (195I), DNA by the method of Burton (1956) and RNA by the method of Harry \& Umbreit (1947).

Transformation procedure. This was done according to the method of Avadhani et al. (1969). About $\mathrm{IO}^{4}$ mutant cells were inoculated into $5 \mathrm{ml}$. supplemented minimal media and incubated. After incubation for $18 \mathrm{~h}$. inocula of about $10^{5} \mathrm{cells} / \mathrm{ml}$. were transferred to tubes containing $5 \mathrm{ml}$. of the same supplemented medium. The cells were incubated for $5 \mathrm{~h}$., harvested by centrifugation and washed twice with unsupplemented medium. Tubes containing $5 \mathrm{ml}$. unsupplemented minimal medium were inoculated with $10^{6} \mathrm{cells} / \mathrm{ml}$. DNA ( $10 \mu \mathrm{g} . / \mathrm{ml}$.) was added to the cultures and the mixtures incubated for $120 \mathrm{~min}$. The DNA reaction was terminated by addition of $2 \mu \mathrm{g}$. DNase $/ \mathrm{ml}$. in $0.03 \mathrm{M}-\mathrm{MgSO}_{4}$. Dilutions of the suspension were plated on minimal agar and the number of transformed cells determined by colony counts after $48 \mathrm{~h}$. incubation. Experimental controls were suspensions of mutant cells incubated without addition of DNA. Sterility of the DNA preparations was determined by incubation in nutrient broth.

Effect of preconditioning on recipient cells. The strain I3 mutant tyr-I leu-1 met-1 was grown for $18 \mathrm{~h}$. in minimal medium supplemented with the required amino acids. Twenty $\mathrm{ml}$. fresh supplemented medium was inoculated with about $10^{4}$ cells $/ \mathrm{ml}$. and incubated. At hourly intervals samples were removed and cells collected by centrifugation. After washing twice with unsupplemented medium about $10^{6}$ cells $/ \mathrm{ml}$. were transferred to tubes containing $5 \mathrm{ml}$. unsupplemented minimal medium. DNA ( $10 \mu \mathrm{g} . / \mathrm{ml}$.) was added to the cultures and transformation performed as above.

Effect of concentration of DNA on transforming frequency. DNA at concentrations of 0.5 to $20 \mu \mathrm{g} . / \mathrm{ml}$. was employed in transformation experiments using the triple mutant tIr-I leu-I met-I as recipient. Techniques were as described above.

\section{RESULTS}

Composition of the transforming principle. The DNA extraction procedure yielded a preparation with a $E_{260} 280$ value of $\mathrm{I} \cdot 4 \pm 0 \cdot \mathrm{I}$. This preparation contained $95.0 \% \mathrm{DNA}, \mathrm{I} \cdot 7 \%$ protein and $2 \cdot 3 \%$ RNA (w/w).

Transformation assays. Using wild-type strain 13 as donor of DNA, 35 out of 40 independent preparations of DNA produced transformation of auxotrophs. Average yields from these experiments are listed in Table I.

Extraction and purification of transforming DNA. Biologically active DNA was only 
obtained when it was extracted at a pH between 8.5 and 9.5 . Chilled conditions were also essential for biological activity. DNA prepared at room temperature did not possess transforming activity.

Table I. Transformation of mutant cells of Proteus mirabilis and $P$. vulgaris with DNA from wild-type P. mirabilis strain $\mathrm{I} 3$

\begin{tabular}{ll} 
Strain & \multicolumn{1}{c}{ Genotype } \\
I3 & tyr-I leu-I met $-I$ \\
I3 & tyr-I ade-I met $-I$ \\
I3 & leu-I met - I his $-I$ \\
5006 & ade $-I$ \\
5006 & arg-I \\
69 & ura-I $(P$. vulgaris $)$
\end{tabular}

Colony count $/ \mathrm{ml}$.

\begin{tabular}{|c|c|c|c|}
\hline \multirow{2}{*}{$\begin{array}{l}\text { Supplemented } \\
\text { medium }\end{array}$} & \multicolumn{2}{|c|}{ Unsupplemented medium } & \multirow{2}{*}{$\begin{array}{c}\text { Transforma- } \\
\text { tion }(\%)\end{array}$} \\
\hline & DNA present & DNA absent & \\
\hline $1.40 \times 10^{6}$ & $3.4 \times 10^{4}$ & 0 & $2 \cdot 43$ \\
\hline $\mathrm{r} \cdot 80 \times 10^{6}$ & $4.6 \times 10^{4}$ & 0 & $2 \cdot 56$ \\
\hline I. $40 \times 10^{6}$ & $5.1 \times 10^{4}$ & 0 & 3.64 \\
\hline $\mathrm{I} \cdot 50 \times 10^{6}$ & $7 \cdot 2 \times 10^{4}$ & $3.6 \times 10^{1}$ & 4.80 \\
\hline $1.46 \times 10^{5}$ & $6.5 \times 10^{4}$ & $2.4 \times 10^{1}$ & $4 \cdot 45$ \\
\hline $1 \cdot 54 \times 10^{6}$ & $3.0 \times 10^{1}$ & $2.8 \times 10^{1}$ & 0 \\
\hline
\end{tabular}

Table 2. Effect of growth of recipient cells of strain 13 in supplemented medium on the number of transformants

$\begin{array}{cccc}\begin{array}{c}\text { Time of } \\ \begin{array}{c}\text { incubation } \\ \text { (h.) }\end{array}\end{array} & \begin{array}{c}\text { Supplemented } \\ \text { medium }\end{array} & \begin{array}{c}\text { Unsupplemented } \\ \text { medium }\end{array} & \begin{array}{c}\text { Transformation } \\ (\%)\end{array} \\ \text { I } & 2.0 \times 10^{6} & 3.0 \times 10^{1} & \text { Negligible } \\ 2 & 3.4 \times 10^{6} & 4.0 \times 10^{2} & 0.01 \\ 3 & 6.0 \times 10^{6} & 3.6 \times 10^{4} & 0.60 \\ 4 & 3.0 \times 10^{6} & 6.3 \times 10^{4} & 2 \cdot 10 \\ 5 & 3.2 \times 10^{6} & 9.8 \times 10^{4} & 3.06 \\ 6 & 2.2 \times 10^{6} & 3.3 \times 10^{4} & 1 \cdot 50 \\ 8 & 5.4 \times 10^{6} & 1.0 \times 10^{1} & 0.02 \\ \text { I0 } & 8.3 \times 10^{6} & 4.2 \times 10^{1} & \text { Negligible } \\ \text { I5 } & 8.6 \times 10^{6} & 4.0 \times 10^{1} & \text { Negligible }\end{array}$

Table 3. Transformation with DNA isolated from mutant I 3 tyr-I leu-I met-I

$\begin{array}{ll}\text { Strain } & \text { Gecipient } \\ \text { I3 } & \text { tyr-I leu-I met }- \text { I } \\ \text { I3 } & \text { tyr }-I \text { ade }-I \text { met }-I \\ 13 & \text { leu-I met }-I \text { his }-I \\ 5006 & \text { ade }-I \\ 5006 & \text { arg-I }\end{array}$

$\begin{array}{ccc}\begin{array}{c}\text { Supplemented } \\ \text { medium }\end{array} & \begin{array}{c}\text { Colony count/ml. } \\ \text { medium }\end{array} & \begin{array}{c}\text { Trans- } \\ \text { formation } \\ (\%)\end{array} \\ 1 \cdot 74 \times 10^{6} & 0 & 0 \\ 1 \cdot 83 \times 10^{6} & 0 & 0 \\ 1.45 \times 10^{6} & 0 & 0 \\ 1 \cdot 55 \times 10^{6} & 7.8 \times 10^{4} & 5.0 \\ 1 \cdot 37 \times 10^{6} & 5.2 \times 10^{4} & 3.8\end{array}$

Competence of recipient cells. Preconditioning of the recipient cells was important for transformation. Maximal transformation was obtained in cells of strain 13 tyr-I leu-I met-I incubated for $5 \mathrm{~h}$. in supplemented minimal medium before exposure to DNA (Table 2).

Transformation of mutants with DNA extracted from auxotrophic cells. DNA extracted from the triple mutant tyr-I leu-I met-I failed to transform the mutants tyr-I ade-I his-I and leu-I met-I his-I. The mutants ade-I and arg-I were converted to amino acid independence by this DNA with the same efficiency as was obtained with DNA isolated from the wild strain (Table 3). 
Transformation and concentration of DNA. Fig. I demonstrates the effect of DNA concentration on the number of transformants obtained. The number of transformants increased with DNA concentration to an optimum at $16 \mu \mathrm{g} . / \mathrm{ml}$.

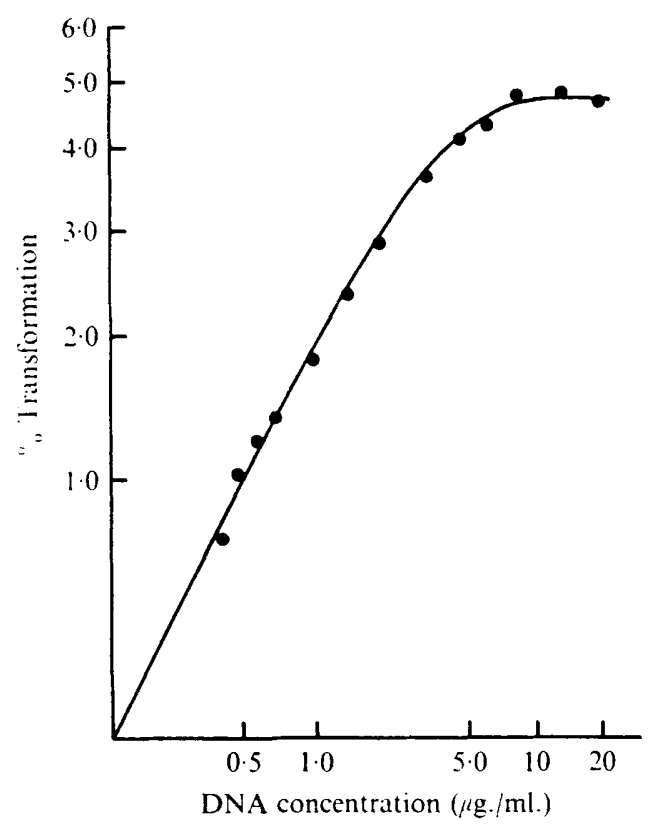

Fig. I. The effect of DNA concentration on transformation in Proteus mirabilis. Cells from mutant $t y r-I$ leu-I met-I were subjected to wild-type DNA at different concentrations $(0.5$ to $20 / \mathrm{g} . / \mathrm{ml}$.). Number of transformed colonies were counted at each concentration.

\section{DISCUSSION}

Despite numerous publications on transformation in bacteria only a few deal with this phenomenon in Enterobacteriaceae (Chargaff et al. 1957; Mehta et al. 1962; Avadhani et al. 1969). The transformation described here was dependent on a number of factors. First, the method of DNA preparation was important as no biological activity was observed with DNA obtained by phenol extraction. The temperature and $\mathrm{pH}$ of lysates during DNA extraction and subsequent RNase treatment were also critical. Inactivation by residual DNase present in the lysate may account for these results. The number of transformants was also dependent on the growth conditions of recipient cells preceding and during exposure to DNA. A similar phenomenon was encountered with transfection in these strains (van Rensburg, 1969) and may be related to the phenomenon of competence observed with pneumococci (McCarty, Taylor \& Avery, 1946). Mutants of Proteus mirabilis strain 5006 (the only other tested) yielded transformants with the heterologous DNA at about the same efficiency. Reasons for the failure to transform the $P$. vulgaris strain are being investigated at present. Non-specific stimulation of growth of auxotrophic cells by DNA was excluded as a factor in these results because DNA extracted from mutant tyr-I leu- $r$ met-I failed to transform the isogenic strain. We failed to demonstrate phage development in spheroplasts from auxotrophic strains simultaneously exposed to DNA from prototrophic cells (van Rensburg, 1970). Rudchenko (I968) succeeded with this latter type of experiment in an Escherichia coli system. An explanation for this failure may be that 
transformation rates are low and transfection rates even lower (van Rensburg, 1969). Chargaff et al. (1957) stated: 'The complete isolation of DNA from Escherichia coli is not easy. It is possible that the unsatisfactory quality of many of the specimens isolated by previous workers is one of the reasons for the scarcity of information on bacterial transformation in this genus.' This statement can be confirmed because not only had experimental techniques to be precise but transformation was only achieved with DNA extracted in the cold and at a $\mathrm{pH}$ above $8 \cdot 5$.

Genetic analysis of Proteus has been dependent on transduction (Coetzee \& Sacks, 1960), conjugation (Falkow, Wolhieter, Citarella \& Baron, 1964) and transfection (van Rensburg, 1969). These techniques have now been complemented by those of transformation. Because of the efficiency of DNA transfer in the latter procedure it may serve as an ideal tool for fine structure analysis. The Proteus system now compares favourably with those of Escherichia coli and Bacillus subtilis and awaits exploitation.

This work was aided by grants from the South African Council for Medical Research to Professor J. N. Coetzee.

\section{REFERENCES}

Adelberg, A., Mandel, M. \& Chen, G. C. C. (1965). Optical conditions for mutagenesis by $N$-methyl$N^{\prime}$-nitro- $N$-nitrosoguanidine in Escherichia coli $\mathrm{K}$ I2. Biochemical and Biophysical Research Communications $18,788-795$.

Avadhani, N. G., Mehta, B. M. \& Rege, D. V. (1969). Genetic transformation in Escherichia coli. Journal of Molecular Biology 42, 413-423.

Burton, K. (1956). A study of the conditions and mechanism of the diphenylamine reaction for the colorimetric estimation of deoxyribonucleic acid. Biochemical Journal 62, 31 5-323.

Chargaff, E., Schulman, H. M. \& Shapiro, H. S. (1957). Protoplasts of E. coli as sources and acceptors of deoxypentose nucleic acid: Rehabilitation of a deficient mutant. Nature, London 180, 851-852.

Coetzee, J. N. (1963). Lysogeny in Proteus rettgeri and the host-range of $P$. rettgeri and $P$. hauseri bacteriophages. Journal of General Microbiology 31, 219-229.

CoETzEe, J. N. \& SACKs, T. G. (1960). Transduction of streptomycin resistance in Proteus mirabilis. Journal of General Microbiology 23, 445-455.

Coetzee, J. N. \& Smit, J. A. (1970). Properties of Proteus mirabilis phage i3vir. Journal of General Virology 9, 247-249.

Falkow, S., Wolhieter, J. A., Citarella, R. V. \& Baron, L. S. (I964). Transfer of episomic elements to Proteus. I. Transfer of F-linked chromosomal determinants. Journal of Bacteriology 87, 209-219.

HarRY, G. A. \& UmbreIt, W. W. (1947). Differentiation between ribose-3-phosphate and ribose-5-phosphate by means of the orcinol-pentose reaction. Journal of Biological Chemistry 167, 369-376.

KAISER, A. D. \& HogNess, D. S. (1960). The transformation of Escherichia coli with deoxyribonucleic acid isolated from bacteriophage $\lambda d g$. Journal of Molecular Biology 2, 392-4I 5.

KaUfFMann, F. (1966). The Bacteriology of Enterobacteriaceae. Copenhagen: Einar Munksgaard.

Lowry, O. H., Rosebrough, W. J., FarR, A. L. \& Randall, R. J. (1951). Protein measurement with the Folin phenol reagent. Journal of Molecular Biology 193, 265-275.

Mehta, B. M., Rege, D. V. \& SReenivasan, A. (1962). Transformation to prototrophic condition in Escherichia coli induced by deoxyribonucleic acid. Nature, London 193, 296-297.

MCCARTY, M., TAYLOR, H. E. \& AVERY, O. T. (I946). Biochemical studies of environment factors essential in transformation of pneumococcal types. Cold Spring Harbor Symposia on Quantitative Biology Ir, $177-183$.

ProzesKy, O. W. (1967). Arginine synthesis in Proteus mirabilis. Journal of General Microbiology 49, 325-334.

RUdCHENKo, O. N. (1968). The overcoming of auxotrophy in Escherichia coli spheroplasts dependent on certain amino acids by means of infection with DNAs from prototrophic strains. Genetika 4, 106-1 12.

van ReNSBURG, A. J. (1969). Infection of spheroplasts with DNA from a Proteus mirabilis bacteriophage. Journal of General Virology 5, 437-44I.

van Rensburg, A. J. (1970). Studies on Proteus and Providence Spheroplasts, L Forms and Bacteriophage Nucleic Acids. M.D. Thesis, University of Pretoria, South Africa. 